\title{
A Reformed perspective on the concept of the 'common good' and its relevance for social action in South Africa today
}

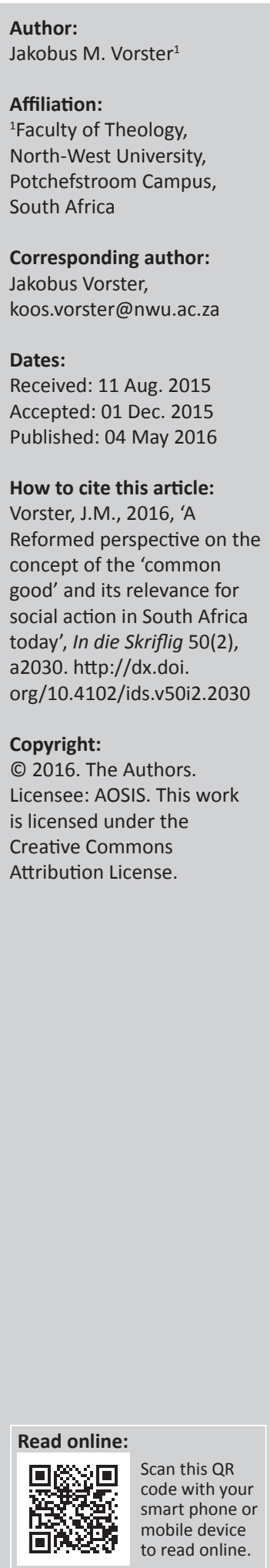

This article investigates the idea of the 'common good' from a Classic Reformed perspective and the possibilities raised by a fresh approach to the concept for social action by civil society in South Africa today. The central theoretical argument of this article is that the new interest in the concept of natural law, as became evident in modern-day moral reflection in the Classic Reformed moral teaching, can indeed contribute to a new positive assessment of the concept common good and can provide a valuable framework for the foundation of reformed social action in cooperation with civil society in South Africa today. Firstly, the concept is discussed within the framework of the reformed idea of 'natural law' and the argument concludes with the finding that the concept can be accommodated in Reformed Theology. Secondly, a case is made for the cooperation between churches, other religious institutions and the broader civil society to cooperate on the basis of the common good and global ethics to address three areas of serious concern in the South African society. These are the promotion of the idea of human dignity within the social sphere with special reference to racism, xenophobia and sexism as well as the development of family life and family values, and the advancement of the idea of neighbourliness as a core ingredient of social healing and reconciliation.

\section{Introduction}

The concept common good is generally associated with Roman Catholic social teaching (see PCJP 2004:83-86). Seen from the perspective of the Roman Catholic tradition, the common good can be understood as the social and communal dimension of the moral good. Roman Catholic moral teaching (PCJP 2004) maintains that:

no expression of social life - from the family to intermediate social groups, associations, enterprises of an economic nature, cities, regions, states up to the community of peoples and nations - can escape the issue of its own common good, in that this is a constitutive element of its significance and the authentic reason for its very existence. (p. 83)

This teaching, which is derived from Augustine's City of God (19.21), insists, according to Langan (1986):

on the conditions and instructions which are necessary for human cooperation and the achievement of shared objectives as decisive normative elements in the social situation, elements which individualism is both unable to account for in theory and likely to neglect in practice. (p. 102)

The concept common good is thus used as a description of what the moral ideals of a community should entail. In Roman Catholic moral teaching the concept is enriched by numerous moral codes that are applicable to social cohesion and action aimed at the edification of society. ${ }^{1}$ This article probes how the Classic Reformed moral teaching, which traditionally restricted moral codes to the ethical directives of Scripture alone, can reflect on this rich tradition in Roman Catholic teaching and what it could mean for civil action directed at community development in South Africa today. Can the concept be accommodated and incorporated in reformed moral teaching and can it be utilised in this tradition to address the task of Christians and churches in their involvement in social action in cooperation with civil society? Can the concept be adapted in the Classic Reformed moral teaching in such a way that its historical richness can be maintained and even strengthened in order to provide moral guidance for social action in society? The central theoretical argument of this article is that the new interest in

1.The intention of this article is not to re-examine the Roman Catholic social teaching regarding the 'common good, but to reflect on the concept's definition and the possibility of its use in the Classic Reformed moral tradition.

Note: This work is based on the research supported by the National Research Foundation (NRF). Any opinion, finding and conclusion or recommendation expressed in this material is that of the author and the NRF does not accept any responsibility in this regard. 
the concept of natural law, as became evident in modern-day moral reflection in the Classic Reformed moral teaching, can indeed contribute to a new positive assessment of the concept common good. It can also provide a valuable framework for the foundation for reformed social action in cooperation with civil society in South Africa today. The argument is then applied to the following focal areas of interest for civil action in South Africa today: the nurturing of the concept of human dignity; the promotion of family-life; and the advancement of the idea of neighbourliness. To clarify this argument, the discussion focuses firstly on the relation between natural law and the 'common good' as found in the Classic Reformed moral teaching; and, secondly, on the chosen topics as described above.

\section{The natural law and the 'common good'}

The concept natural law as the foundation of positive law and moral norms has a long history. This article does not focus on this history, because Weiler (2003:703) has already provided a clear and concise overview of this development in Platonic, Aristotelian and neo-Platonic philosophy and in the theology of Thomas Aquinas. He has explained how this concept became part of Roman Catholic moral teaching. What is relevant for the purposes of this discussion is the way in which John Calvin and his followers entertained the idea of 'natural law'.

Calvin never wrote a complete and systematic thesis on the concept natural law (Schreiner 1991:77). These were produced by his followers such as Vermigli (1499-1562), Zanchi (1516-1590), Turretin (1623-1687) and Althusius (1563-1638) on the basis of Calvin's views. Grabill (2006), Witte (2007) and VanDrunen (2010) have discussed the views of these authors in detail. The concept 'ius naturalis' or 'lex naturae', read with Calvin's views on the principles of the general goodness of God, the doctrine of God's providence and the rights of individuals, is the foundation of Calvin's understanding of civil government and what it entails.

In order to shed some light on his view of the natural law, Calvin's perspective on God's common grace extended to all people and the creation of man in the image of God (imago dei) are important to discuss. According to Calvin, God expressed his common goodness to all people by giving them creational gifts such as a moral sense and a religious inclination (semen religiones). He did not use the term creational gifts, but the term is a distinct summary of his position. To prove his point he refers to the profane authors and contends that the manner in which they explored the truth, proves that they have received abundant blessings that God had extended to depraved humankind (Inst. 2:2:15). ${ }^{3}$ All people thus received creational gifts as a result of the common goodness of God (see also Leith 1989:184; Westermann 1973).

In addition to this observation, Calvin refers to the biblical doctrine of humankind's creation in the image of God (imago dei). The fact that humankind was created in the

2.The author discussed the concept natural law thoroughly in another publication with special application to the hermeneutics of Christian ethics (see Vorster 2014).

3.References to John Calvin's 1559-Institutes are taken from Calvin (2008). image of God is an affirmation of the remarkable gifts that God has bestowed on all people. Arguing from this angle of approach, Calvin draws attention to the basic and inherent dignity of people. Although he does not entertain the term human dignity, he posits that humankind was bequeathed with a special status. People are the most gracious creatures of God's creation and this fact proves the justice, goodness and wisdom of God (Inst. 1:15:1). People reflect the divine glory of God and this reflection is humankind's most remarkable quality. This image is situated in the enlightenment of reason and pureness of heart. Although this image was blemished by the fall, it was not lost or destroyed (Inst. 1:15:4). It will even be fully restored, but this restoration can only be realised by the second Adam, namely Christ. All people therefore received a comprehension of God based on creation and redemption.

To understand people's inherent ability to know God, the reader of Calvin should distinguish between his anthropological and soteriological doctrines. As a result of the fall and humankind's depravity, the fallen people lost their free will and their ability to redeem themselves from the bondage of sin. Seen from a soteriological point of view, humankind was completely lost and became unable to pursue goodness and truth. Calvin (Inst. 2:1:5) used the term original $\sin$ as the concept was used by the early Christian authors to describe the total depravity of all humans. Original sin is, according to Calvin (Inst. 2:1:8), the inherited evil of humankind's nature that encompasses spirit, body and soul. Sin brings people to a state of guilt before God and creates evil deeds that Scripture calls the works of the flesh. In spite of creational gifts to all people, humans became totally depraved and thus unable to secure their own salvation. The only way to salvation for the depraved humankind is the free grace of God, which is expressed in the reconciling sacrifice of Christ, mediated by the Holy Spirit and that can be received by the sinner only through faith and in the spirit of humiliation and repentance (Inst. 3:1:1).

In spite of this soteriology, Calvin founded his anthropology and ethics in the concept imago dei. Although humankind's alienation from God as a result of the fall led to a distortion of the imago dei, God's image in people was not totally destroyed (Inst. 1559:1:15:4). People maintain a dignity and they must abide by the responsibilities flowing from this dignity. In his explanation of the scope of the Christian love, Calvin (Inst. 3:7:6) asserts that God's commandment to love all people and to do good to all people derives from the fact that God has bestowed dignity on all people. Believers should always see and respect the image of God in other people. As proof of this point of view, he refers to Genesis 1:27. He pleads that people should regard each other as fellow human beings with inherent dignity in the eyes of God.

In his distinction between the spiritual and the civilian kingdoms Calvin (Inst. 2:7:1) referred to natural law (lex naturae) as a created moral law bestowed on humankind and that this law rules over both kingdoms. This moral law is engraved in the conscience, affirmed in Scripture and 
summarised in the Decalogue. To explain this idea, the metaphor of concentric circles can be utilised. The outside circle is the natural law engraved in the conscience. The inner circle is the revelation of God in the written Word or Scripture. The centre is the Decalogue as it is summarised in various parts of Scripture. The moral law that is engraved in the conscience of humankind is described by Calvin with many terms. Witte (2007:59) has mentioned a few: 'the voice of nature'; 'the engraved law'; 'the law of nature'; 'the natural law'; 'the inner mind'; 'the rule of equity'; 'the natural sense'; 'the sense of divine judgement'; 'the testimony of the heart'; 'the inner voice' and others. These terms are well-described by Bohatec (1934:3; 1962:19). VanDrunen (2010) has also provided an extended explanation of these concepts in his recent publication. All these concepts, as they are employed by Calvin points to the fact that God has bestowed creational gifts to all people which entails that non-believers can also realise justice, can make morally sound decisions and can maintain law and order in society. In this respect he followed the views of the predecessors of the Reformation (McNeil 1965:20). Calvin (Inst. 2:7:1) thus regarded the lex naturae as a gift to humankind, which entails a moral sense. In his introduction to the explanation of the Decalogue he firstly paid attention to this 'law' that has been given by God to all people. In his commentary on Romans 2:14-15 he also maintained that the sense of law and justice is engraved in the hearts of all people (Calvin 1964:48). He entertained the same idea in his sermons on Deutoronomium 4:44-6:4 and 19:14-15.

Every person has a moral sense and an engraved inclination for justice and therefore has the responsibility to realise morality and just laws. However, this inclination does not justify the sinner before God. It has a social dimension only and is an indication of the equality and human dignity of all people. The purpose of this creational gift is to maintain a certain level of morality and civil justice to prevent the creation from falling into total disorder.

Although Calvin did not present a comprehensive thesis on natural law, his contemporary, Vermigli (1499-1562), and his followers, Althusius (1563-1638) and Turretin (1623-1687), developed his ideas and applied them to ethics, politics and law. Turretin (1997:1:3:4) has followed in the footsteps of Calvin and gave the following reasons for God's creational gift of natural law. It is given:

- as a testimony of God's goodness to sinners, which are totally unworthy of such a gift. To prove his point of view he referred to Acts 14:16-17 and John 1:5;

- as a foundation of the external discipline that is necessary to prevent society of becoming absolutely corrupt. In this instance he refers to Romans 2:14-15;

- as a subjective condition of being human to enable people to receive the light of grace because God appeals not to animals, but to rational people;

- as an encouragement to people to seek the more enlightened revelation. In this regard he refers to Acts 14:27;
- as gift that excludes all justification for unbelief and revolt against God and which activates the conscience. In this respect Calvin refers to Romans 1:20; 2:15, 16.

Calvin's exposition of the lex naturae and the calling of all people to realise this in positive law and moral norms had a huge influence on the development of constitutional law. Witte (2007:xi) has described this influence in his research on the development of human rights in early and modern Calvinism. His ideas influenced many and were carried forward by authoritative leaders in France, Netherlands and America in times of constitutional crises. In this respect the names of Theodore Beza (1519-1605), Johannes Althusius (1563-1638), John Milton (1608-1674), John Winthrop (15871649), John Adams (1735-1826) and others can be mentioned. In the modern times his views resonate in the political thought of Kuyper (1916:5), the reformational philosophy of Bavinck (1908:160) and the philosophy of the idea of law of Dooyeweerd (1936). They modernised Calvin's idea of natural law and applied it to dramatic reforms in the fields of law and politics. This idea, amongst others, became a force behind Western constitutionalism. The main contribution of Calvin's idea of natural law was the fact that he acknowledged that, due to God's revelation in nature to all people, it is possible for people to derive universal ethical norms for the organisation of civil life and to prevent chaos. Seen from this point of view a concept such as 'common good' is intelligible and applicable.

This development of the concept of natural law in reformational philosophy and theology receded in the later 20th century due to the influence of scholars such as Barth, Berkhouwer and Van Til (Grabill 2006:6, 190). Against the background of National Socialism's surge and natural theology in Germany, Barth rejected any notion of natural law. In a debate he accused Brunner (Brunner \& Barth 1946), a supporter of Calvin's idea, of misrepresenting Calvin and paving the way of a natural theology with a strong measure of humanism alien to Calvin's idea of total depravity. However, both Grabill (2006) and VanDrunen (2010) are convinced that the idea as it was developed and applied by Calvin and his adherents, receives new positive assessment today and paves the way for the development of moral codes and constitutional ideas in reformational thinking that can contribute to modern-day ethical and political discourses.

Although Grabill and VanDrunen do not refer to the concept common good, a positive appraisal of this Roman Catholic moral teaching can be seen as one of the major derivatives of the idea of natural law. Natural law assures common morals in a pluralist society and a community with various religious persuasions. Arguing from a historical-critical hermeneutic point of view Collins (2005:82) has remarked that a communitarian ethics was at the heart of Israel's religion. The good of the individual was always viewed in the context of the community. In other words, the ethics of the Old Testament had the common good at heart. Irrespective of his critical hermeneutic, this conclusion of Collins is relevant for the argument under discussion. The ethics of Jesus did not deviate 
from the communitarian ethics of the Old Testament as it became evident in his emphasis on the great commandment, the golden rule and love of the enemy.

The renewed interest in this Classic Reformed concept of natural law consequently enables modern-day reformed scholars to develop a fresh and positive appraisal of the common good. In this respect the political thinking of Rawls comes to mind. What Rawls $(1993 ; 1999)$ has said about overlapping consensus regarding plurality in politics is also true when addressing the common good. In Rawls's view a well-ordered society needs an overlapping consensus that allows for a plurality of reasonable, though opposing, comprehensive doctrines, each with its own conceptions of the good (see also Vorster 2010:595). A well-ordered society can be stable when a political concept of justice can be offered that every supporter of a reasonable doctrine can endorse from his or her own philosophical, ideological or moral point of view. Applied to civil society, this overlapping consensus entails that the purpose-driven civil society can find common ground on the common good for a certain cause. The concept common good, as seen from a reformed perspective, can thus be defined as a set of social principles and ethical norms that are universally acceptable and applicable. That can be pursued by Christians, other faith traditions and civil society in order to reach certain moral ends. The actions of civil society can thus function on the basis of an overlapping consensus on moral directives that can drive civil action. Due to shared values emanating from natural law, churches can cooperate with civil society to pursue a certain cause based on shared convictions.

What are the challenges inherent to the concept of the common good as defined according to the above-mentioned reformed paradigm for civil action in South Africa today? In the next part of this article three challenging topics are highlighted in this respect. These are essential components of the common good that should receive special attention from churches and civil society in a joint effort to serve community development in South Africa today. The topics under investigation are the nurturing of the principle of human dignity, the promotion of family-life and the advancement of the idea of neighbourliness. Civil action in South Africa should focus especially on these critical social issues.

\section{Focal issues in the pursuit of the common good in South Africa The nurturing of human dignity}

The concept imago dei constitutes the basic dignity of people. Human dignity is a gift from God. Various reformed scholars draw attention to the importance of the acknowledgement of people's basic human dignity as a result of God's creational gifts (Barth 1961:116; Berkhouwer 1957:34; 356; Moltmann 1993:2210; Pannenberg 1977:13; Westermann 1973:103; Wright 2004:119). This dignity is furthered by the fact that God gave people the breath of life, as explained by the biblical concept nefesj. The word nefesj in die Old Testament means life - the life of human beings as well as animals (see Gn 1:20; Lv 17:11 and Dt 12:23). It cannot be derived from this word alone that the life of humans has greater value than that of animals, but the theological context of this concept is important. Unlike animals, human beings are created in a relationship with God and with each other. Human life comes from God. Brueggemann, Petersen and Faithein (1999:51) has said in this regard, 'God's very life is then breathed into the sinner; something of God's own self becomes an integral part of human identity, enabling life to move from God out into the larger world.' This life is more than biological life. Human beings receive spirit - a spirit that does not seize with biological death, but that will continue to exist after the biological death in the presence of God (see Ps 16:10; 86:13; 89:49). Therefore the concept life is important in any theological reflection (Wüstenberg 1996:136).

Humans have an inherent dignity and this value forms the basis of all relationships. It entails that human beings must treat each other with respect and that human life is sacred and should be protected. Human dignity, as the fruit of the creation of humans in the image of God and the bestowal of the breath of God, should direct human relations and the regulation of society. Therefore, human dignity can be regarded as the foundational value of the common good. In the organisation of society the concept human dignity is utilised in the development of an ethos and practice of human rights. Human rights have become the most important ethical issue in Christianity in modern times (Martinez 1986:270). Rights, however, are meaningless without morals, as Küng (1997:102) has reminded us. The idea of the common good and its basic value of all people's dignity have the ability to cherish and develop the moral foundation of the quest for human rights. Therefore, virtually all faiths and ideologies found human rights in the concept of human dignity and the morals flowing from this idea. Due to its high valuation of human dignity as a creational gift from God, reformed moral teaching should be involved, along with other faith traditions and ideologies in the world-wide process of nurturing human dignity and in the promotion of the cause of human rights everywhere.

With the inception of the Universal Declaration of Human Rights in 1948 (United Nations 1995:128), the idea of human rights and the constitutional state took root and influenced many societies for the better. People come to realise that 'The human rights violations of today are the wars of tomorrow'. ${ }^{4}$ Abuses of people and violations of fundamental human rights cause strife and wars as the great wars of the early 20th century proved. However, reformed churches are not as involved in furthering human rights as they should be. At first the Classic Reformed moral teaching was suspicious of the concept due to its perceived 'humanist nature'. The author has explained the reasons and extent of this negative approach in another publication (see Vorster 2004:57). The situation has improved, but much has still to be done to

4.This statement was made by Mary Anderson at the 56th session of the Human Rights Commission of the United Nations in Geneva, March 2000. 
create responsiveness in civil society and state institutions for the promotion of the fundamental human rights of people in countries where abuses and violations of human rights are endemic. This is especially true of Reformed Churches in South Africa (Olivier 2011). With a rich theological tradition regarding the calling of Christians in the public sphere against the background of natural law and human dignity, reformed moral teaching can raise awareness of the fundamental human rights of every person and consistently call on the government to honour and protect these rights. In this process civil society should be involved on the basis of a common sharing of these fundamental principles.

Three areas in the public domain can be identified as problem areas in the current South African context: racism, xenophobia and sexism. Race relations in South Africa have improved since the inception of democracy in 1994. De iure racism has been phased out with the inception of the Constitutional Democracy. Reconciliation and transformation had positive effects due to the initiatives of the Truth and Reconciliation Commission and the efforts of the successive administrations since 1994. However, in spite of these laudable developments, South Africa is still far from a non-racial and reconciled community and is still dealing with de facto racism. Racist attitudes are still prevalent in the form of emotion, feeling and bias as defined by Marger (1994:452). This form of racism is still alive in schools, universities, labour unions and even churches. What is needed is a comprehensive approach by religion, civil society and the government to educate and equip society to root out all prevailing pockets of racist ideas and behaviour. This can be done by furthering the concept of the common good that holds the principle of human dignity and human rights in high esteem. South Africans must be guided to embrace the common good in order to integrate into a reconciled community.

Xenophobic attacks have plagued the South African society since 2008. Foreigners who entered South Africa, legally and illegally, are blamed by South Africans of 'stealing' the locals' jobs by working for less than the minimum wages in corporations, industries, mines and on farms. They are also accused of manipulating small businesses in townships by benefitting other foreigners to the detriment of local business people. A wave of anti-foreigner sentiment amongst local South Africans in townships resulted in two waves of serious violent attacks in 2008 and 2015 on foreign businesses when many businesses were looted and burned down. As early as 1999, the South African Human Rights Commission took a strong position against any form of xenophobia. The Commission has stated, inter alia, that xenophobia is a deep dislike of non-nationals by nationals of a recipient state and its manifestation is a violation of human rights. Furthermore, the Commission urged South Africa to send out a strong message that an irrational prejudice and hostility towards non-nationals is not acceptable under any circumstances. Criminal behaviour towards foreigners cannot be tolerated in a democratic society. The Commission also stated that South Africans should seek to construct a society where human dignity, the achievement of equality and the advancement of human rights and freedoms are abiding values. The Bill of Rights confers certain rights to 'everyone'. These are rights to equality, human dignity, the right to life, freedom and security of person, and the right not to be subjected to slavery, servitude and forced labour (South African Human Rights Commission 1999:133).

The struggle against xenophobia and the nurturing of an ethos of respect and fundamental human rights is an area where churches can mobilise civil society on the basis of a mutual consensus on the common good to become active. The Christian message about the treatment of foreigners is clear not only based on the New Testament commandment of love for the neighbour, but also on the Old Testament ethics of good relationships, especially the relationship with alien people in a good neighbourhood. Miller (2004:53) has indicated how the construction of the Decalogue, which begins with the phrase: 'I am the Lord your God', and ends with 'neighbour', forms a community. The Decalogue proclaims a community, which does not constitute itself or evolve, but becomes defined due to a relationship between God and people. This community is a morally constituted community consisting of all neighbours including foreigners and immigrants, that is people who move into the neighbourhood, but do not belong to the family, the clan or the ethnic community (see Ex 12:19, 49; 20:10; Dt 5:14; Lv 19:33-34; 24:22; Nm 9:14; 15:15-16; 15:29-30). The moral character of God's people is, inter alia, determined by their moral treatment of the others. Love of 'the other', even 'the enemy', is deeply entrenched in Christian morality and Christians have to testify to this code in social life. Therefore, Christians should be the voice of ill-treated foreigners and the church and civil society can mobilise in a joint venture to raise awareness of the emigrants' plight in South Africa and to promote peaceful neighbourhoods.

In addition, the South African society is still plagued by violations of the fundamental rights of women and young girls. In many respects in cultural, family and social life they are treated as inferior. Although this inferiority is no longer entrenched in social institutions, it is still very much alive in patriarchal families and in churches. Furthermore, women are the victims of poverty more often than men due to migrant labour and joblessness of their male companions. What is even more disturbing is the negative role of religion in the prevailing inferior position of women. SchüsslerFiorenza (1998:23) has asserted two decades ago that religion played and is still playing a major role in the establishment and continuation of this inferior position of women in societies. This point of view has been reaffirmed by Gudorf (2007). Their observations are still true of society in Africa and South Africa today. Banda (2005:172) has explained that there has been an explosion of newer Christian churches in Africa whose members comprise mainly women. He laments the fact that in these movements the translation and interpretation of religious texts have often resulted in women being told that it is their duty to submit themselves to their husbands or partners. 
South Africa has made great strides in the recognition of the role of women in government and business, and the present administration can be commended for their advancement of women's fundamental rights in the social sphere. However, religions and religious institutions fall short in this regard. If religion teaches society that women are inferior the advancement of women's rights in all spheres of life will be in vain. To pursue the common good in cooperation with civil society Classic Reformed moral teaching have to promote the fundamental rights of women by initiating and promoting a thorough and far-reaching discourse on gender and gender relations. This tradition should specifically address the tenability of patriarchal family relations and the androcentric definitions of the role of women in family-life and in ecclesiastical institutions, because partriarchalism was part and parcel of reformed moral teachings over the centuries, and churches in this tradition are still plagued by the remnants of those teachings.

\section{The promotion of family life}

The last four decades witnessed tremendous and wide-ranging changes in family patterns in Western societies. Amongst these changes are phenomena such as growing divorce rates, out-ofwedlock births and father absence due to globalisation as well as same-sex marriages and cohabitation without a marriage contract (Browning 2001a:243). Western societies are typified as 'high-divorce societies'. Furthermore, the number of couples cohabiting in the US has increased eightfold since 1970 and it is fair to conclude that the situation is similar in other Western societies. Gill (1997:81) has expressed the concern of many Christians with his observation that we are faced with a rapid decline in two-parent families, a rise in both teenage pregnancies and abortions, the spread of the HIV epidemic, vociferous gay activism and widespread confusion about the legal and social limits of pornography and obscenity. These tendencies are also noticeable in the South African society.

In a well-documented article, Browning (2001b:4) has found that the phenomena of modernisation and globalisation are at the root of these disrupting forces in patterns of family life. In the ethical discourse about these developments, the question is raised by many scholars whether these developments should be regarded as immoral or as normal cultural patterns in a changing society? Are they merely an indication of changes in family life determined by new social conditions, or can they be regarded as part of an emerging moral crisis? Hauerwas (1981:155) asked this question already in 1981.

Browning (2001a:247) has identified three kinds of responses to this question in Christian ethical circles. These are liberal theological views that perceive these patterns as normal and in line with modern human rights sensitivities, the conservative theological view, which regards them as immoral and contrary to biblical commandments, and the Catholic view, which is also conservative (for an explanation of the Catholic view see Keane 1980; PCJP 2004). However, in another equally well-researched publication, Browning (2001b:4) has ventured to answer this question and refers in this regard to recent publications dealing with these changing patterns in family life and concludes that there has been a worldwide transformation in the attitudes within the social sciences towards these changes since the late 1980s. He says that sociologists, psychologists and economists are nowadays much more willing to acknowledge that these developments have been damaging to large numbers of people. Changes in family patterns have contributed to the declining well-being of children and they have been concomitant with the 'feminisation of poverty' (the shift of poverty from the elderly to single mothers and their children) as well as the 'feminisation of kinship' (the trend towards women sustaining families alone, without the help of fathers and husbands). In other words, although most social scientists now concur that these changes have been costly to individuals and society, they disagree about whether they can be reversed or whether they must simply be accepted in the hope of mitigating their negative consequences.

Closer to home, a recent study of Denis (2015) in this regard has revealed shocking and distressing realities in the decline of family life in a large sector of the South African society. Denis (2015) has revealed that in the rural parts of South Africa families have virtually disappeared and the concept of a monogamous family has largely become obsolete. In his view young people do not know this concept anymore. This situation is the result of the century-old pattern of migrant labour in South Africa where the fathers moved to the industrial parts of the country to work away from home and their families to support the mining industry and to escape their poverty at home. Due to the Native Labour Regulation Act (Union of South Africa 1911) and the well-known Land Act (Union of South Africa 1913) black families were not permitted to move with the fathers to the cities that were designated white areas. Other ill effects of these two bills are adequately described by Terreblanche (2002:269). The black mineworkers resided in all-male compounds where many died of illnesses from nutritionally poor diets, inadequate sanitation and rampant respiratory diseases (Maloka 1997:242). They were away from their families for long periods and as a result the families became impoverished. Denis (2015) has pointed out other negative effects, such as:

- the total absence of the educational and disciplinary role of the father in the households;

- the feminisation of poverty and the resulting lack of education of women;

- the rise of a large number of single parent families;

- the lack of development of schools, hospitals and clinics in rural areas due to the allocation of resources in the booming mining industries;

- the disruption of the stable tribal systems;

- the development of 'second families' in the growing cities by the men that left their first families in the rural areas;

- the increase of alcohol abuse and prostitution in the allmale compounds.

Denis (2015) has investigated the hearings of the South African Native Affairs Commission in 1911 and indicated 
how churches supported the migrant labour system and that they were more concerned about the lack of morality in the compounds than the immoral set-up of the whole system of racial segregation and the migrant labour system. Today the South African society is reaping the fruits of this system and the effects are still felt in townships' churces and the rural areas in spite of the fact that families can move freely to the cities where labour is more available. The ill effects of the migrant labour's system were vividly displayed in the Marikana tragedy when police shot 34 protesting miners who still suffered from the negative effects of the migrant labour system. This incident illustrated the huge challenge facing the churches and civil society in South Africa today to improve family life and to deal with the negative effects of the policies of the past.

The author discussed a Christian view of marriage and family and what it entails for family life today in another publication (see Vorster 2007:185-207). Most of the values expressed in the publication are shared in the common good that religion and civil society strive after. These are a good and loving marital relationship of equal partners characterised by mutual trust, faithfulness, compassion, servanthood and love; family life where children are secure and educational opportunities are accessible and a safe and secure environment favourable for decent living conditions. To pursue the common good in this regard amidst the crisis in family life in South Africa today will entail the following:

- the development of a sound and applicable ethic of family life by the religious communities and the promotion of this ethic by civil societies involved in education and human development;

- the system and practice of migrant labour should be dealt with in light of the principle of human dignity and what it entails. This aspect is an area where religion and civil society can become deeply involved to assist government and business to find solutions for the inhumane nature of this practice and its dehumanising social effects such as the feminisation of poverty, destruction of family systems and unhealthy living conditions. Trade unions are playing a positive role in the improvement of the living conditions of migrant workers and should, in this respect, be morally supported by Christian churches and other religious institutions on the basis of the principle of the common good;

- the South African government is deeply involved in various housing projects at the national, regional and local levels. However, many informal townships still exist and homelessness is a huge problem. This situation can also be related to the growing phenomenon of urbanisation. In this area civil society can be involved in a positive way by assisting government in the development of sustainable housing policies. The expertise available in civil institutions can add value to the formulation and implementation of government policies. Churches are very influential in local communities, especially in poverty stricken-rural areas. As part of civil society they are in an excellent position to raise awareness of the need for rural development and to motivate civil society to become active in seeing to the needs of rural communities.

Although South Africa embarked on the road of neo-liberal economic policies, the government is also actively and directly involved in the alleviation of poverty by way of social grants to 17 million citizens. This endeavour should be lauded. However, in the end poverty can only be alleviated by sound and effective economic policies. In this respect also the Classic Reformed moral teaching on stewardship and on the role of the state as a moral agent in the alleviation of poverty by the execution of responsible economic policies, can contribute to a better society for all. Furthermore civil society should be encouraged to mobilise its own expertise to assist the government and government officials should be open and accommodating regarding the inputs of civil society.

These are a few proposals offered to illustrate the important role churches and civil society can play in developing family life in South Africa and to curb the negative influences of social patters that destroys family life. A positive appraisal of the concept of the common good and the resulting broad scope it brings to the fore for civil society and civil action raises the possibility of vigorous involvement of civil societies in social development. The third component of the common good that should receive special attention from churches and civil society in a joint effort to serve community development in South Africa today is the advancement of the idea of neighbourliness.

\section{The advancement of the idea of neighbourliness}

The Roman Catholic Compendium of the Social Doctrine of the Church states that the common good involves all members of society and no one is exempt from cooperating according to their possibilities in attaining and developing it (PCJP 2004:84). Due to this emphasis and calls within the contemporary ethical discourse in various traditions, the concept 'neighbourliness' has made inroads into the contemporary social ethical discourse. This new development is a result of the world-wide concern about divisions between people based on religion, ethnicity, race, culture, et cetera, and results in acts of violence and even war. The violence resulting from religious extremism is the most devastating form of division that threats societies today. This fact is evident from the $9 / 11$ and $7 / 7$ terrorist attacks on the US and UK respectively as well as the recent spate of religiously motivated terrorist attacks in Tunisia, Nigeria, Kenia, Syria, Saudi Arabia, France, Turkey and other states by groups such as Islamic State, Boko Haram, El Shabbab and Al Kaida. Due to these actions, new forms of divisions have arisen with the capacity to cause new wars and conflicts between nations. Ateek (2008:156) has asserted that, as long as we divide the world and our own communities into friends and enemies, neighbours and strangers, we feel no moral obligation towards those whom we have already designated as outsiders. The distinction between ' $u$ ' and 'them' create binary societies. Ateek's observation is exactly what is happening in many communities today due to the newfound religious extremism. 
In this context the concept neighbourliness comes to mind and it is essential that this concept should be developed on the basis of natural law and applied in religiously divided communities. Küng (1997) has already paved the way for research in this regard with his plea for a global ethic resulting from dialogue between religions. Christian theologians have since explored this idea further and developed the concept in view of biblical theology (see e.g. Everist 2011). Miller (2004:142) has explained how the orientation of the Decalogue in the Old Testament is always towards the other, whether the other is the God whose proper worship is the ground of all other acts, or the neighbour, brother or sister. Miller (2004) commented as follows:

The rights of the individual are presumed, but the way into those rights is always by way of responsibility for the neighbour. 'My' rights, 'my' well-being and the like are insured and protected not by any claims or actions of my own, but by my being a neighbour to others who stand under the same responsibilities toward me that I have toward them. (p. 142)

A seminal study on the concept and meaning of neighbourliness in the Christian tradition was done by Brueggemann (2010). This study was done in the midst of the economic collapse of the post-2008 period and the antiterrorist wars since 2001. He applied various Old Testament texts to a reconstruction of society and to building bridges between divided communities and nations. He posits that many parts of the Old Testament such as the Exodus narrative, the Jeremiah oracle and the Isaiah sequence of texts provide material on which a theology of the common good and a journey towards true neighbourliness can be constructed. This research provides Reformed Theology with a suitable foundation for more thorough reflection on the principle and practical application of neighbourliness in divided societies

Neighbourliness entails the endeavour to heal divisions and to bridge deep differences with a fixed purpose by way of dialogue and cooperation. The concept natural law in Reformed Theology and a positive assessment of the Roman Catholic concept of the common good are good foundations for the pursuit of neighbourliness by churches and civil society today. These institutions can further dialogue and cooperation to promote bridge-building in the midst of the racial, ethnic, social and religious divides. The advancement of an ethos of neighbourliness is of paramount importance in South Africa today. Datta (2012) has provided a good example of what can be attained in this regard with his study on neighbourliness in a Delhi squatter settlement. He (Datta 2012:760) has concluded that slums in Delhi, which he has described as a 'mongrel city', became places where a bridge across differences of caste, religion, ethnicity and language is an ordinary aspect of everyday life. These settlements became places of compassion. Such bridges must be built in the divided South African society.
The following pre-conditions can be defined as necessary to develop an ethos of neighbourliness:

- a mutual respect for the inherent human dignity of every person;

- regarding every person, near and far away, as a neighbour (Everist 2011:157);

- openness to 'others';

- a movement away from the worldview of antithesis, which was propagated by the Classic Reformed moral teaching in the past, to a worldview of synthesis, acceptance and accommodation;

- respect for other cultures, worldviews, religions and social statuses;

- the mutual searching of the common good in every situation of conflict and division.

Churches should advance the idea of neighbourliness in the social sphere and inspire civil society to nurture and apply this concept in their endeavours aimed at the moral development of the South African society.

\section{Conclusion: Church, civil society and the common good in South Africa}

The common good is much more than a simple socioeconomic well-being (PCJP 2004:86). This idea encompasses every attempt to improve human existence spiritually, socially, morally and economically. Classic Reformed moral teaching can be enriched by the concept of the common good in this sense. The pursuance of the common good is a logical consequence of the theology of natural law. With the new discovery of natural law in Classic Reformed moral teaching the concept of common good can form the basis of a fresh moral approach to many pressing issues in South Africa such as the nurturing of an ethos of human dignity and human rights, racism, xenophobia, sexism, the reconstruction of family life, the alleviation of poverty and the promotion of the idea of neighbourliness. In cooperation with other religious traditions and civil society, Classic Reformed moral teaching can be instrumental in civil action aimed at the improvement of human life in South Africa.

\section{Acknowledgements Competing interests}

The author declares that he has no financial or personal relationship(s) that may have inappropriately influenced him in writing this article.

\section{References}

Ateek, N., 2008, 'Who is my neighbour?', Interpretation 62(2), 156-165.

Banda, F., 2005, Women, law and human rights: An African perspective, Portland Oregan, Oxford.

Barth, K., 1961, Church dogmatics, vol. 3: The doctrine of creation, part 4., transl. A.T. Mackay, T.H.L. Parker, H. Knight, H.A. Kennedy \& J. Marks, Clark, Edinburgh. Bavinck, H., 1908, Wijsbegeerte der Openbaring, Kok, Kampen.

Berkhouwer, G.C., 1957, Dogmatische studiën: De mens het beeld Gods, Kok, Kampen. Bohatec, J., 1934, Calvin und das Recht, Bolhaus, Vienna. 
Bohatec, J., 1962, Calvins lehre von Staat und Kirche, mit besonderer Berucksichtigung des Organismus gedankens, Scientia Aalen, Breslau.

Browning, D., 2001a, 'World Family Trends', in R. Gill (ed.), The Cambridge companion to Christian ethics, pp. 243-260, Cambridge University Press, Cambridge.

Browning, D., 2001b, The world situation of families: Marriage reformation as a cultural work, T\&T Clark, Edinburgh.

Brueggemann, W., 2010, Journey to the common good, Westminster John Knox Press, Louisville, KY.

Brueggemann, W., Petersen, D.L. \& Faithein, T.E., 1999, A theological introduction to the Old Testament, Abington, Nashville, TN.

Brunner, E. \& Barth, K., 1946, Natural theology, Geoffrey Bles, London.

Calvin, J., 1964, Commentary upon the epistle of Saint Paul to the Romans, Calvin Translation Society, Edinburgh.

Calvin, J., 2008, Institutes of the Christian religion, Hendriksen, Peabody, MA.

Collins, J.J., 2005, Encounters with biblical theology, Fortress Press, Minneapolis, MN.

Datta, A., 2012, “"Mongrel city”: Cosmopolitan neighbourliness in a Delhi squatter settlement', Antipode 44(3), 745-763.

Denis, P., 2015, 'Lazy natives and labour shortage: The colonial church's historical responsibility in the dismantlement of the family in South Africa', paper presented at the annual meeting of the Theological Society of South Africa, Pietermaritzburg, 17th June. (Copy available at author).

Dooyeweerd, H., 1936, De wijsbegeerte der wetsidee, deel 3, H.J. Paris, Amsterdam.

Everist, N.C., 2011, 'The Church's vocation in society through the ministry of the laity in the languages of their daily lives', Dialogue: Journal of Theology 50(2), 154-161.

Gill, R., 1997, Moral Leadership in a postmodern age, T\&T Clark, Edinburgh.

Grabill, S.J., 2006, Rediscovering the natural law in Reformed Theological Ethics, Eerdmans, Grand Rapids, MI.

Gudorf, C.E., 2007, 'Violence against women in world religions,' in D.C. Maguire \& S Shaik (eds.), Violence against women in contemporary world religion, pp. 9-29, Pilgrim Press, Cleveland, $\mathrm{OH}$.

Hauerwas, S., 1981, A community of character: Toward a constructive Christian socia ethic, Notre Dame, London.

Keane, P.S., 1980, Sexual morality a Catholic perspective, Gill \& Macmillan, Dublin.

Küng, H., 1997, A global ethic for global politics and economics, SCM Press, London.

Kuyper, A., 1916, Antirevolutionaire staatkunde, Kok, Kampen.

Langan, S.J.,1986, 'Common good', in J.F. Childress \& J. Macquarrie (eds.), The Westminster dictionary of Christian ethics, p. 102, Westminster, Philadelphia, PA.

Leith, J.H., 1989, John Calvin's doctrine of the Christian life, Westminster, Louisville.

Maloka, T., 1997, 'The struggle for sunday: All-male christianity in the gold mine compounds', in R. Elphick \& R. Davenport (eds.), Christianity in South Africa: A political, social and cultural history, pp. 242-253, David Philip, Cape Town.

Marger, M.N., 1994, Race and ethnic relations: American and global perspectives, Wordsworth, Belmont, CA.

Martinez, P., 1986, 'The right to be human', Evangelical Review of Theology 10(5), 270-276.

McNeil, J.T, 1965, 'John Calvin and civil government', in G.L. Hunt (ed.), Calvinism and the political order, pp. 20-35, Westminster, Philadelphia, PA.
Miller, P.D. 2004, The way of the lord: Essays in Old Testament Theology, William B. Eerdmans, Grand Rapids, MI.

Moltmann, J., 1993, God in creation, Fortress, Minneapolis, MN.

Olivier, E., 2011, 'Violence: The Church is part of the problem', Verbum et Ecclesia 32(2), 510, 5 p. http://dx.doi.org/10.4102.v32i2.510

Pannenberg, W., 1977, Human, nature, election and history, The Westminster Press, Philadelphia, PA.

Pontificial Council for Justice and Peace (PCJP), 2004, Compendium of the socia doctrine of the Church, Libreria Editrice Vaticana, St Pauls Publications, Strathfield.

Rawls, J., 1993, Political liberalism, Columbia University Press, New York.

Rawls, J., 1999, A theory of justice, Harvard University Press, Cambridge, MA.

Schreiner, S.E., 1991, The theatre of his glory: Nature and natural order in the thought of John Calvin, Baker Book House, Grand Rapids, MI.

Schüssler-Fiorenza, E., 1998, Sharing her word: Feminist biblical interpretation in context, T\&T Clark, Edinburgh.

South African Human Rights Commission, 1999, 'The Braamfontein statement: Racism and Xenophobia: A violation of human rights', South African Journal of Human Rights 15, 133ff.

Terreblanche, S., 2002, A history of inequality in South Africa 1652-2002, University of Natal Press, Pietermaritzburg.

Turretin, F., 1997, Institutes of elenctic theology, vol. 1, transl. G.M. Geiger, T \& T Publishing, Phillipsburg, NJ.

Union of South Africa, 1911, Native Labour Regulation Act, Government Printer, Pretoria.

Union of South Africa, 1913, Land Act, no. 27, Government Printer, Pretoria.

United Nations, 1995, The United Nations and Human Rights 1945-1995, United Nations, New York.

VanDrunen, D., 2010, Natural law and the two kingdoms: A study in the development of reformed social thought, Eerdmans, Grand Rapids, MI.

Vorster, J.M., 2004, Ethical perspectives on human rights, Potchefstroom Theological Publications, Potchefstroom.

Vorster, J.M., 2007, Christian attitude in the South African liberal society, Potchefstroom Theological Publications, Potchefstroom.

Vorster, J.M., 2014, Christelike etiek in 'n sekulariserende samelewing, AOSIS e-boeke, Kaapstad, viewed 1 July 2015, from http://www.dx.doi.org/10.4102/aosis. ceiss.2014.01.

Vorster, N., 2010, 'Are freedom and equality natural enemies? A Christian-Theological perspective', The Heythrop Journal, A Bimonthly Review of Philosophy and Theology 51(4), 594-609.

Weiler, R., 2003, 'Natural Law', in E. Fahlbusch, J.M. Lochman \& J. Mbiti (eds.), The encyclopedia of Christianity, vol. 3., pp. 703-706, Eerdmans, Grand Rapids, MI.

Westermann, C., 1973, Forschung am Alten Testaments: Gesammelte Studien, Band 2, Christliche Kaiser Verlag, München.

Witte, J., 2007, The reformation of rights. Law, religion, and human rights in early modern Calvinism, Cambridge University Press, Cambridge.

Wright, C.J.H., 2004, Old Testament ethics for the people of God, InterVarsity, Leicester.

Wüstenberg, R.F., 1996, A theology of life, transl. D. Stott, Eerdmans, Grand Rapids, MI. 